a paper entitled "The Geometrical Theory of Diffraction". A good deal of attention was given to a paper concerned with the 'creeping wave' in the theory of diffraction. It outlined a method for problems concerned with the diffraction by objects not larger than about a hundred wave-lengths; the asymptotic expansions can then no longer be used, as there may be a considerable contribution from a wave creeping around the back of the object.

As already mentioned, one session was devoted to Fourier transforms and information theory. Accounts of useful Fourier and operational techniques were given and various applications described. Some analogies between optics and information theory were noted. This session as well as the round-table conference on Fourier transforms suggest that Fourier transforms and information theory are likely to play an increasingly important part both in light and microwave optics.

On several occasions during the symposium, attention was directed to investigations in related subjects closely analogous to the work described, and it became apparent that there is a good deal of overlapping and repetition in the two main fields. But no one who was present in the crowded sessions at McGill could have departed without being stimulated by the variety of ideas and by the impressive record of work carried out in microwave optics during the past few years. The only criticism which may be raised refers to the fact that each speaker was allowed only 10-15 minutes, a period certainly not sufficient for the presentation of some of the subjects. It is, however, easy to understand the difficulties with which the organizers of any large scientific gathering are faced in this connexion. To some extent these difficulties were overcome at McGill by the distribution, prior to the opening session, of mimeographed volumes containing summaries of all the papers. An extended version of these volumes will shortly appear as a special issue of the Canadian Journal of Physics and will undoubtedly become an important contribution to the literature on microwave optics.

$$
\text { E. WOLF }
$$

\section{CENSUS OF WOODLAND AREAS LESS THAN FIVE ACRES IN GREAT BRITAIN}

$\mathrm{T}$

$\mathrm{HE}$ first report of the census of woodlands in Great Britain, carried out during 1947-49, gave the statistics for the area and stocking of woodlands of five acres and more (see Nature, August 8, p. 240). The second report, which has now been published*, provides the additional data, collected during 195051 , and completes the census in respect of all timber which could be included as forming part of the national resources available in time of need and of a reserve which, given reasonable care and management, will continue to grow and produce more timber. The relative importance of these small woods and scattered trees is not generally appreciated except by the few directly concerned, though the war-time (1942) survey had indicated that they carried something like one-fifth of the total timber volume in the country. The figure for hedgerow and park timber

* Forestry Commission. Census Report No. 2: Hedgerow and Park Timber and Woods under Five Acres, 1951. Pp. $88+12$ plates. (London : H.M.S.O., 1953.) 5s. net. now arrived at for the whole of Great Britain is 807 million cubic feet and that for the small woods 222 million cubic feet, forming 21 and 6 per cent respectively of the total volume of 3,773 million cubic feet (this includes the large woods). Moreover, the average size of the trees in the hedgerows, parks and small woods is appreciably greater than that in the larger woods, this fact being largely ascribable to the concentration of war-time fellings on the larger woods and on the older crops in them.

Of particular interest in the present survey are the methods adopted for collecting the necessary field data and for computing the results with a measure of the probable errors involved. For the hedgerows and parks, the method already established in the 1938 and 1942 surveys was retained. It consisted in the field examination of a strip 44 yards wide, drawn on selected Ordnance Survey quarter sheets on the scale of six inches to a mile. The percentage of sampling is a very low one, one acre in roughly eight thousand, built up of three independent random sets of the Ordnance Survey maps. The standard error, as a percentage of the actual volume, is computed at 8.5 per cent; this is low enough for all practical purposes, though it does not permit of a reliable break-down of the figures into countries and conservancies-thus the standard error for Scotland alone would be 25 per cent.

As might be expected, the five common hedgerow species, oak, elm, ash, beech and sycamore, are found to constitute the bulk of the volume, about fourfifths of the total, oak with 34 per cent and elm with 19 per cent alone contributing half by number of trees and slightly more by volume. The prospects of maintenance of this resource by growth and recruitment are considered. It is thought that there are enough saplings to maintain the numbers of small hedgerow trees, but the distribution of size classes suggests that the volume of larger hedgerow timber is likely to diminish unless further planting (or storing) is carried out.

For the small woods, between one and five acres, the methods are much more closely linked with the survey of the large woods. Small woods were already known to aggregate 187,000 acres, about 5 per cent of the total woodland area. Again a sampling method was adopted, involving the field examination of small woods in the south-western quarter of each of the Ordnance Survey six-inch quarter sheets selected for the hedgerow census, in the same three samples. This worked out at an aggregate 0.92 per cent sample. These woods were classified into the same types as were differentiated for the large woods, and it is assumed that the average stocking per acre for each type is the same for both categories of size. The objections to this assumption-and they may well be viewed as rather serious-are recognized; but the considerable additional work involved in obtaining independent estimates was not felt to be justified. Since the surveys were made, 5 per cent of the area shown as small woods has been lost to other forms of land use, as compared with 2 per cent of the large woods: this reduces the total area to 178,000 acres comprising 71,730 woods fairly equally distributed between 1-2, 2-3, 3-4 and 4-5 acre units. The current annual growth or volume increment of the trees in these woods is estimated at 5 million cubic feet, to be compared with 97 million in the large woods.

It was thought desirable and worth while, in the course of this census, to collect the necessary data 
for obtaining a rough estimate of the limited volumes of timber standing in the woodlands classified in the main census as simple coppice, scrub, devastated woods and felled woodland. In these types, there were often thinly scattered trees for which no estimate of volume was made at that time. One sample, usually one acre in extent, was measured on each type in each of the quarter-sheet maps used for the hedgerow estimates. The data indicate a total volume of 85.6 million cubic feet, fairly equally divided between the felled and devastated types taken together and the simple coppice taken with the scrub.

Summarizing the current growth data for all the timber of Great Britain, the combined census arrives at a figure of 115.5 million cubic feet annually on the growing stock of 3,773 million cubic feet, or 3 per cent. This amount is not, of course, available for immediate use, as apart from amenity considerations, much of it, particularly for the conifers, must be retained in the standing crops to grow to larger size. With the completion of this national inventory Britain moves into line with the still limited number of countries that have reliable statistics for their forest resources. It remains to keep the information up to date by a regular programme of field-work, since adjustment for estimated growth and reported fellings are inadequate for the purpose: this, it is believed, is being done by the Forestry Commission.

H. G. Champion

\section{CHARACTERISTICS OF THE IONOSPHERE IN GREAT BRITAIN}

$\mathrm{O}^{2}$ $\mathrm{NE}$ of the major items in the programme of radio research conducted by the Department of Scientific and Industrial Research during the past twenty-five years has been the development and maintenance of ionospheric recording stations in Great Britain. Following the research work of Sir Edward Appleton and his co-workers at the Cavendish Laboratory, Cambridge, and the Radio Research Substation, near Peterborough, measurements were begun in 1929 at the Radio Research Station, Slough. In the following year a technique for measuring the critical frequency of the $E$-region was developed from experiments carried out between a transmitting station at the National Physical Laboratory, Teddington, and receiving stations at the Radio Research Station, Slough, and the Halley Stewart Laboratory, London. This enabled the present series of ionospheric measurements to begin in January 1931. As the experimental techniques developed and as knowledge of the complexity of the ionosphere increased, the scope and frequency of the measurements have expanded until, at the present time, observations are made every hour and recorded photographically.

An account of this development of the study of the characteristics of the ionosphere in Britain is described in Radio Research Special Report No. 23 of the Department of Scientific and Industrial Research*, which describes the general nature of the results obtained and illustrates the variation in the measured characteristics of the ionosphere during the period 1931-46.

For the past few years the results of such measurements have been compiled in tabular form and either

* Department of Scientiflc and Industrial Research, Special Report No. 23: Characteristics of the Ionosphere observed in Great Britain durilig 1930-1946. Pp. vi +16. (London : H.M.S.O., 1953.) 18. 6d. net. circulated on an exchange basis to other organizations issuing similar information, or distributed to scientific workers and engineers who have a need for such knowledge in connexion with their research or with the various applications of radio transmission. There exists, however, a large quantity of observational material of great geophysical value accumulated in Britain which has hitherto not been available except in limited amounts and on specific request. The present publication is intended to remove this limitation, and to make available to all who are interested the accumulated results of the past work in this field. The complete data are comprised in nearly eight hundred tables of the results of observations made at the Radio Research Station, Slough, during the years 1930-46, and at Burghead, Scotland, during 1941-46. These tables, which are listed in appendixes to the report, reflect the gradual building up of the observational measurements as knowledge of the subject grew and as the experimental techniques available have developed to that of the present type of fully automatic equipment taking photographic records every hour.

Because of the expense, it is not possible to publish the tables in printed form, and arrangements have been made to make photo-copies available. These may be consulted at the Technical Information and Documents Unit of the Department of Scientific and Industrial Research, Cunard Building, 15 Regent Street, London, S.W.1, or by arrangement at the Radio Research Station, Ditton Park, Slough. Each table is on a separate sheet. A minimum of ten consecutive tables on microfilms can be supplied at $3 d$. per table and a microfilm copy of all tables costs £3 3s. Enlargements on sheets 9 in. by 7 in. are available at $1 s$. per table. Sets of not less than a hundred consecutive tables can be supplied at $£ 210 s$. per hundred net. Requests for copies of the tables, which should quote table numbers, place of observation (that is, Slough or Burghead) and the form in which they are required (that is, microfilms or sheets) should be addressed to H.M. Stationery Office, P.O. Box 569, London, S.E.1.

The published report and the availability of the results in the above manner are likely to be of great value not only to those directly interested in the transmission of radio waves by means of the ionosphere, but also to those engaged in scientific research in related geophysical fields, such as solar phenomena, the upper atmosphere or the earth's magnetic field.

\section{THE EXPRESSIONS 'GOLGI APPARATUS', 'GOLGI BODY' AND 'GOLGI SUBSTANCE'}

\author{
By DR. JOHN R. BAKER \\ Department of Zoology, University Museum, Oxford
}

$T$ HERE are certain objects in cells, such as the nucleus, which obviously correspond from cell to cell and for which special names are necessary. The name 'Golgi apparatus' is commonly used with the implication that it refers to homologous bodies that exist in all or nearly all cells of animals. I myself formerly believed that nearly all cells of animals did, in fact, contain such homologous bodies, to which it was appropriate to give a single name. 